\title{
STRUCTURE AND MAGNETIC PROPERTIES OF $\left[\left(\mathrm{CH}_{3}\right)_{3} \mathrm{NH}\right] \mathrm{MnCl}_{3} \times 2 \mathrm{H}_{2} \mathrm{O}$ CRYSTALS
}

\author{
V. Kapustianyk ${ }^{1}$ (D), Yu. Chornii ${ }^{1}$ (D), P. Demchenko ${ }^{2}$ (D), E. Khatsko \\ ${ }^{1}$ Faculty of Physics, Ivan Franko National University of Lviv, \\ 50, Drahomanov St., Lviv, UA-79005, Ukraine, \\ ${ }^{2}$ Faculty of Chemistry, Ivan Franko National University of Lviv, \\ 8, Kyrylo \&s Mefodiy St., Lviv, UA-79005, Ukraine, \\ ${ }^{3}$ B. Verkin Institute for Low Temperature Physics and Engineering, National Academy of Sciences of Ukraine, \\ 47, Nauky Ave., Kharkiv, UA-61103, Ukraine, \\ e-mail:ychornii@gmail.com
}

(Received 13 November 2020; in final form 27 January 2021; accepted 28 January 2021; published online 03 June 2021)

\begin{abstract}
The X-ray powder diffraction study of $\left[\left(\mathrm{CH}_{3}\right)_{3} \mathrm{NH}\right] \mathrm{MnCl}_{3} \times 2 \mathrm{H}_{2} \mathrm{O}(\mathrm{TrMAMnCl})$ single crystal confirmed the chemical composition and symmetry of the investigated compound and refined the lattice parameters in comparison with the previous data: $a=16.7492(7), b=7.4241(3)$, $c=8.2119(3) \AA$, unit cell volume $V=1021.13(7) \AA^{3}$. Temperature and field dependences of the magnetization of $\mathrm{TrMAMnCl}$ single crystals have been measured. They shown that $\mathrm{TrMAMnCl}$ behaves as a canted one-dimensional antiferromagnet with the Neel temperature $T_{\mathrm{N}}=0.98 \mathrm{~K}$. Taking into account the data of ESR, magnetic specific heat and structural study, behavior of the magnetization can be explained by assumming that there is a hidden canting of the spin along the $b$ axis in the investigated crystal. The broad maximum of the magnetization observed at $T=2.5 \mathrm{~K}$ (just above the ordering temperature) was related to the effect of the noticeable shortrange order by analogy with the related compounds with alkylammonium cations and linear chains of the magnetic ions complexes.
\end{abstract}

Key words: antiferromagnet, magnetic properties, magnetization, low-dimensional spin systems, $\mathrm{X}$-ray powder diffraction.

DOI: https://doi.org/10.30970/jps.25.2701

\section{INTRODUCTION}

The magnetic behavior of low-dimensional spin systems has recently come under intensive study. $\left[\left(\mathrm{CH}_{3}\right)_{3} \mathrm{NH}\right] \mathrm{MnCl}_{3} \times 2 \mathrm{H}_{2} \mathrm{O}(\mathrm{TrMAMnCl})$ crystals belong to the compounds with chemically chained $\mathrm{Mn}(\mathrm{II})$ complexes with weak links between the chains and are a logical choice for such studies.

The structure of TrMAMnCl was for the first time presented in [1]. According to that paper, the crystal belongs to the orthorhombic symmetry with the space group Pnma. The lattice constants were found to be: $a=16.733 \AA, b=7.422 \AA$ and $c=8.198 \AA$. This compound contains polymeric $\mathrm{MnCl}_{2}$ chains which are parallel to the $b$ axis. The distance between the nearest $\mathrm{Mn}$ ions along the $b$ axis was found to be $3.711 \AA$. The ratio of the intra-chain $\mathrm{Mn}-\mathrm{Mn}$ distance to the inter-chain distance is $1: 2.2$, which is compared with the ratios 1:2.8 and 1:1.3 for the related linear chain compounds $\left[\left(\mathrm{CH}_{3}\right)_{4} \mathrm{~N}\right] \mathrm{MnCl}_{3}(\mathrm{TrMAMnCl})$ and $\mathrm{CsMnCl}_{3} \times 2 \mathrm{H}_{2} \mathrm{O}$ [1]. The reported magnetic susceptibility for this magnetic crystal has shown these compounds to be antiferromagnetically ordered at the lowest temperature $\left(T_{\mathrm{N}} \approx 1 \mathrm{~K}\right)$ with a canted spin structure [2,3]. Unfortunately, although Merchant et. al [2] investigated two isomorphic compounds $\left[\left(\mathrm{CH}_{3}\right)_{3} \mathrm{NH}\right] \mathrm{MnBr}_{3} \times 2 \mathrm{H}_{2} \mathrm{O}$ and $\left[\left(\mathrm{CH}_{3}\right)_{3} \mathrm{NH}\right] \mathrm{MnCl}_{3} \times$ $2 \mathrm{H}_{2} \mathrm{O}$ - they have presented the dependences reflecting the magnetic properties only of the former of the two because both crystals are similar in this respect. They only announced a more exact Neel temperature for
TrMAMnCl: $T_{\mathrm{N}}=0.98 \mathrm{~K}$. This value was also confirmed by the magnetic specific heat and ESR study [4].

Taking into account that the crystals with transition metal complexes and alkylammonium cations were found to be magnetic multiferroics [5-7], a precise study of the magnetic properties of $\left[\left(\mathrm{CH}_{3}\right)_{3} \mathrm{NH}\right] \mathrm{MnCl}_{3} \times 2 \mathrm{H}_{2} \mathrm{O}$ compound would be considered as a very interesting fundamental and applied problem.

Finally, if we take into account that the exchange interaction perpendicular to the $b$ axis chain is considerably weaker than that along the chain, $\mathrm{TrMAMnCl}$ is suggested to be a one-dimensional (1D) antiferromagnet with the spin $S=5 / 2$ and the Neel temperature $T_{\mathrm{N}}=$ $0.98 \mathrm{~K}[4,8]$.

\section{EXPERIMENTAL}

The samples of $\left[\left(\mathrm{CH}_{3}\right)_{3} \mathrm{NH}\right] \mathrm{MnCl}_{3} \times 2 \mathrm{H}_{2} \mathrm{O}$ were grown at a constant temperature from the aqueous solutions of $\left[\left(\mathrm{CH}_{3}\right)_{3} \mathrm{NH}\right] \mathrm{Cl}$ and $\mathrm{MnCl}_{2} \times 4 \mathrm{H}_{2} \mathrm{O}$ salts taken in the stoichiometric ratio using the slow evaporation method.

$\mathrm{X}$-ray powder diffraction (XRPD) data were collected in the transmission mode using a STOE STADI $\mathrm{P}$ diffractometer [9] with the following setup: $\mathrm{Cu} K \alpha_{1^{-}}$ radiation, curved Ge (111) monochromator on primary beam, $2 \theta / \omega$-scan, angular range for data collection 6.995-90.305 $2 \theta$ with increment 0.015 , linear position sensitive detector with the step of recording $0.480^{\circ} 2 \theta$ and time per step $440 \mathrm{~s}, U=40 \mathrm{kV}, I=37 \mathrm{~mA}, T=25^{\circ} \mathrm{C}$. A calibration procedure was performed utilizing SRM 
640b (Si) and SRM $676\left(\mathrm{Al}_{2} \mathrm{O}_{3}\right)$ NIST standards. Preliminary data processing and X-ray phase analysis were performed using STOE WinXPOW [9] and PowderCell [10] program packages. The crystal structure was refined using the Rietveld method with the program FullProf.2k (version 5.40) [11, 12], applying a pseudo-Voigt profile function.

The magnetization $M$ of a single-crystal sample of TrMAMnCl was measured in the temperature range of $1.8-200 \mathrm{~K}$ along the principal axes of the crystal with the use of an MPMS-XL Quantum Design SQUID magnetometer. The measurement field was 100 Oe and the sample's sizes were $0.3 \times 0.3 \times 0.7 \mathrm{~mm}$. The largest value of $M$ was found to be along the $b$ axis. Therefore, detailed investigations of the magnetic properties were performed applying the magnetic field in this chosen direction.

The field dependences of the magnetization $M(\mathrm{H})$ were measured at fixed temperatures in the vicinity of the ordering temperature $1.8-10 \mathrm{~K}$ and with magnetic fields up to $14 \mathrm{~T}$.

\section{RESULTS}

The X-ray diffraction study was performed in order to confirm the chemical composition and symmetry of the investigated single crystals. The grown light pink crystals were crushed into a grayish white powder for XRPD. $\mathrm{X}$-ray phase analysis confirmed the bulk homogeneity and showed the presence of $\left[\left(\mathrm{CH}_{3}\right)_{3} \mathrm{NH}\right] \mathrm{MnCl}_{3} \times 2 \mathrm{H}_{2} \mathrm{O}$ compound. Its crystal structure has been completely determined using $2 \mathrm{X}$-ray single crystal diffraction data in [13].

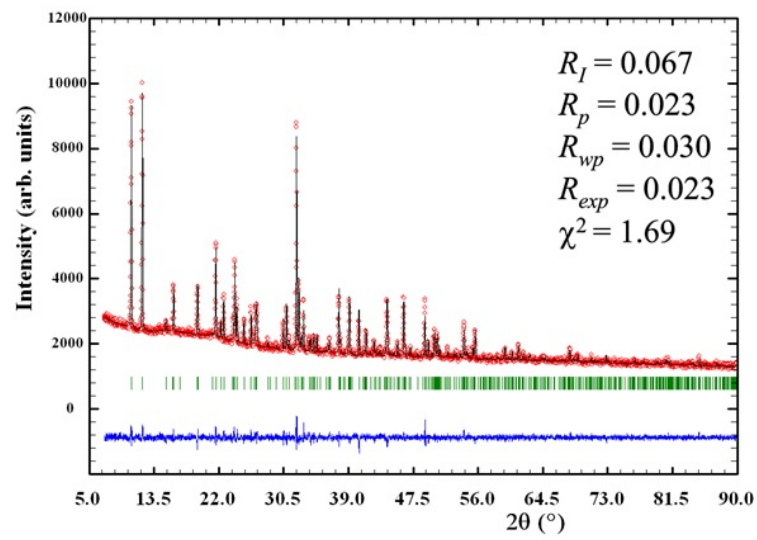

Fig. 1. Observed and calculated X-ray powder profiles for $\left[\left(\mathrm{CH}_{3}\right)_{3} \mathrm{NH}\right] \mathrm{MnCl}_{3} \times 2 \mathrm{H}_{2} \mathrm{O}$ sample. Experimental data (circles) and calculated profile (solid line) are given with calculated Bragg positions for $\left[\left(\mathrm{CH}_{3}\right)_{3} \mathrm{NH}\right] \mathrm{MnCl}_{3} \times 2 \mathrm{H}_{2} \mathrm{O}$ (vertical ticks), difference curve (bottom solid line) and values of reliability factors after Rietveld refinement

Rietveld refinement was performed using the structural model [13], with fixed positions of hydrogen atoms, and gave the more precise lattice parameters in comparison with the data of $[1,13]: a=16.7492(7)$, $b=7.4241(3), c=8.2119(3) \AA$, unit cell volume $V=$ 1021.13(7) $\AA^{3}$ (space group Pnma) (Fig. 1).

Studying the magnetic properties of TrMAMnCl crystal it is necessary to bear in mind that the ground term of the $\mathrm{Mn}^{2+}$ ions is ${ }^{6} \mathrm{~S}$, and the magnetic moment corresponds to $S=5 / 2$ with an isotropic $g$ factor $g=$ $2.00[4]$.

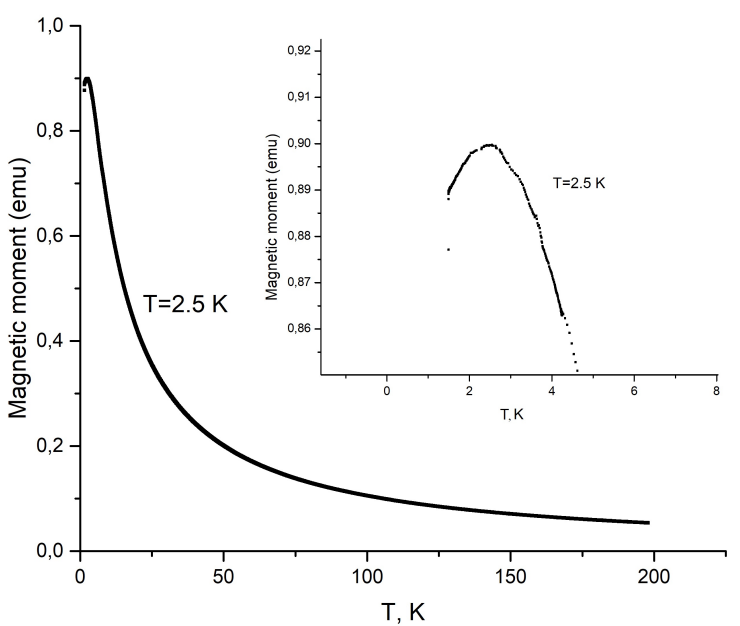

Fig. 2. The magnetization measured along the $b$ axis as a function of temperature

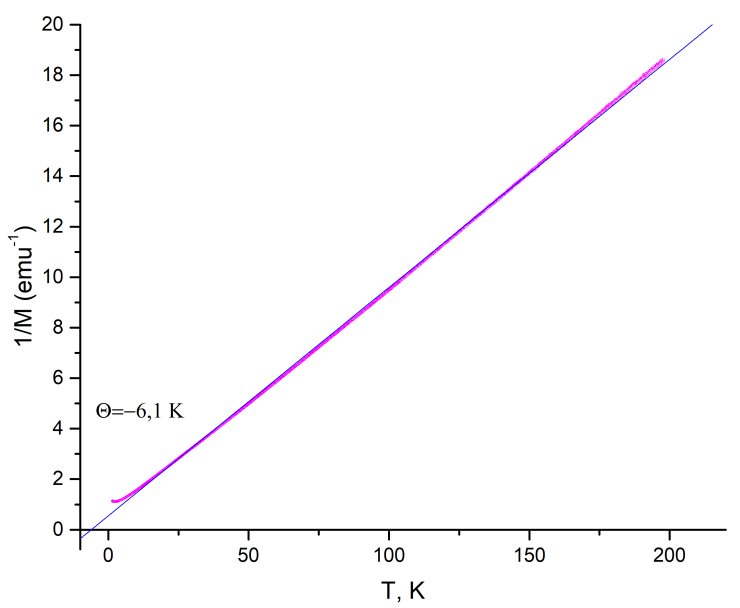

Fig. 3. The inverse magnetization as a function of temperature (solid line presents a linear fit)

The magnetization of TrMAMnCl single crystal measured along the $b$ axis as a function of temperature is presented in Fig. 2. It shows the dominant paramagnetic behavior at $T>5 \mathrm{~K}$. Unfortunately, we could not reach the Neel temperature $T_{\mathrm{N}}=0.98 \mathrm{~K}$. The broad maximum observed above the ordering temperature - at $T=2.5 \mathrm{~K}$ - would be related to the effect of the noticeable short-range order which was observed in the related compounds with a linear chain of transition metal complexes [14]. Moreover, this conclusion correlates with the data of ESR and the magnetic specific heat study of TrMAMnCl crystal [4]. 
At above $17 \mathrm{~K}$, the magnetization of the crystal is well described by the Curie-Weiss law (see the solid line in Fig. 3) with the Curie-Weiss temperature of $\theta=-(6.1 \pm$ $0.1) \mathrm{K}$. Given the sign of the Curie-Weiss temperature, it is possible to conclude that the exchange interaction between the $\mathrm{Mn}^{2+}$ ions in the chains is antiferromagnetic [15].

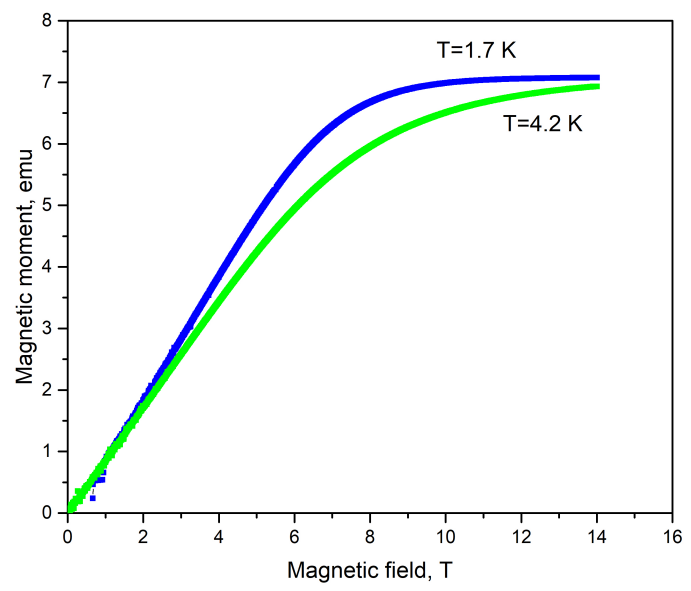

Fig. 4. Magnetic field dependences of the magnetization in vicinity of the ordering temperature

The sharp rise of the magnetization at temperature below $25 \mathrm{~K}$ is reminiscent of the behavior of the corresponding magnetic susceptibility of TrMACoCl [3] and $\mathrm{TrMAMnBr}$ [2] compounds. This behavior can be explained if we assume that there is a hidden canting of the spin along the $b$ axis in the investigated crystal. The magnetic behavior was interpreted in terms of a collection of one-dimensional linear chains of the manganese-chloride complexes, with weak antiferromagnetic coupling along the chain as well as between the chains. This is consistent with the structural results. The bridging $\mathrm{Mn}-\mathrm{Cl}-\mathrm{Mn}$ angles of $94.83^{\circ}$ and $92.13^{\circ}$ are in the range where ferro- and antiferromagnetic superexchange contributions are expected to roughly cancel each other. The hydrogen-bonding network provides a superexchange mechanism between the chains [13]. The reported magnetic susceptibility for this magnetic crystal also has shown them to be antiferromagnetically ordered at the lowest temperature $(T \approx 1 \mathrm{~K})$ with a canted spin structure [16].

This conclusion also correlates with a considerable nonlinearity of the field dependences of the magnetization observed at the relatively high values of the magnetic field in the temperature range just above the ordering temperature and the mentioned temperature $T=$ $2.5 \mathrm{~K}$, respectively (Fig. 4). Such a behavior confirms the suggestion about a hidden canting of the spin along the $\mathrm{b}$ axis in the investigated crystal.

\section{CONCLUSIONS}

The X-ray diffraction study confirmed the chemical composition and symmetry of the investigated TrMAMnCl single crystals and refined the lattice parameters in comparison with the data of $[1,13]: a=$ 16.7492(7), $b=7.4241(3), c=8.2119(3) \AA$, unit cell volume $V=1021.13(7) \AA^{3}$ (space group Pnma).

The measurements of the temperature and field dependences of the magnetic parameters have shown that TrMAMnCl behaves as a canted one-dimensional antiferromagnet. Taking into account the data of ESR, magnetic specific heat and structural study $[4,13,16]$, the behavior of the magnetization can be explained if we assume that there is a hidden canting of the spin along the $b$ axis in the investigated crystal. The magnetic properties would be interpreted in terms of a collection of one-dimensional linear chains of the metalchloride complexes, with weak antiferromagnetic coupling along the chain as well as between the chains. The broad maximum of the magnetization observed at $T=2.5 \mathrm{~K}$, namely, above the antiferromagnetic ordering temperature, was related to the effect of the noticeable short-range order by analogy with the related compounds with alkylammonium cations and linear chains of the magnetic ions complexes [2].

Acknowledgement This work was supported by National Research Foundation of Ukraine under the project 2020.02/0130 "Multifunctional organic-inorganic magnetoelectric, photovoltaic and scintillation materials" (Reg. No 0120U104913).
[1] K. Iio, M. Isobe, K. Nagata, J. Phys. Soc. Jpn. 38, 1212 (1975); https://doi.org/10.1143/JPSJ.38.1212.

[2] S. Merchant, J. N. Mc Elearney, G. E. Shankle, R. L. Carlin, Physica 78, 308 (1974); https://doi.or g/10.1016/0031-8914(74) 90073-1.

[3] D. B. Losee et al., Phys. Rev. B 8, 2185 (1973); https: //doi.org/10.1103/PhysRevB.8.2185.

[4] S. Chikazawa, T. Sato, Y. Miyako, K. lio, K Nagah, J. Magn. Magn. 15-18, 749 (1980); https://doi.org/10 .1016/0304-8853(80) 90747-7

[5] V. Kapustianyk, V. Rudyk, P. Yonak, B. Kundys, Phys.
Status Solidi B 252, 1778 (2015); https://doi.org/10 .1002/pssb. 201451712

[6] B. Kundys et al., Phys. Rev. B 81, 224434 (2010);https : //doi.org/10.1103/PhysRevB.81.224434.

[7] V. Kapustianyk et al., Sci. Rep. 7, 14109 (2017); https: //doi.org/10.1038/s41598-017-14388-8.

[8] T. Tsuboi, J. Phys. Cond. Matt. 5, 1143 (1993); https: //doi.org/10.1088/0953-8984/5/8/016.

[9] Stoe WinXPOW, version 3.03 (Stoe Cie $\mathrm{GmbH}$, Darmstadt, Germany, 2010).

[10] W. Kraus, G. Nolze, PowderCell for Windows, version 


\title{
V. KAPUSTIANYK, Yu. CHORNII, P. DEMCHENKO, E. KHATSKO
}

2.4 (Federal Institute for Materials Research and Testing, Berlin, March 2000).

[11] J. Rodriguez-Carvajal, Newsletter Common on Powder Diffraction of IUCr, 26, 12 (2001);

[12] T. Roisnel, J. Rodriguez-Carvajal, Mater. Sci. Forum 378-381, 118 (2001); https://doi.org/10.4028/www. scientific.net/MSF.378-381.118.

[13] R. E. Caputo, R. D. Willett, J. A. Muir, Acta Cryst. B 32, 2639 (1976); https://doi.org/10.1107/S05677
40876008418.

[14] R. L. Carlin, Magnetochemistry (Springer-Verlag Berlin Heidelberg, Berlin, 1986); https://doi.org/10.1007/ 978-3-642-70733-9.

[15] A. N. Bludov et al., Low Temp. Phys. 46, 643 (2020); https://doi.org/10.1063/10.0001250.

[16] P. K. Majumdar, R. K. Mukherjee, A. K. Banerjee, Phys. Rev. B 41, 65 (1990); https://doi.org/10.1103/Phys RevB.41.65.

\section{СТРУКТУРА Й МАГНІТНІ ВЛАСТИВОСТІ КРИСТАЛІВ $\left[\left(\mathrm{CH}_{3}\right)_{3} \mathrm{NH}\right] \mathrm{MnC1} 1_{3} \times 2 \mathrm{H}_{2} \mathrm{O}$}

\author{
В. Б. Капустяник ${ }^{1}$, Ю. В. Чорній ${ }^{1}$, П. Ю. Демченко ${ }^{2}$, Є. М. Хацько ${ }^{3}$ \\ ${ }^{1}$ Фізичний факультет, Лъвівсъкий начіоналъний університет імені Івана Франка, \\ вул. Драгоманова, 50, Лъвів, 79005, Украӥна, \\ ${ }^{2}$ Лъвівсъкий начіональний університет імені Івана Франка, хімічний факультет, \\ вул. Кирила і Мефодія 8, Лъвів, 79005, Украӥна, \\ ${ }^{3}$ Фізико-технічний інститут низъких температур ім. Б. Веркіна НАН Украйни, \\ просп. Науки 47, Харків, 61103, Украӥна
}

Магнітна поведінка низьковимірних спінових систем останнім часом є об'єктом інтенсивного вивчення. Кристали $\left[\left(\mathrm{CH}_{3}\right)_{3} \mathrm{NH}\right] \mathrm{MnC1}_{3} \times 2 \mathrm{H}_{2} \mathrm{O}(\mathrm{TrMAMnCl})$ належать до квазіодновимірних сполук iз нескінченними ланцюгами, утвореними комплексами Mn (II), причому зв'язки між ланцюгами слабкі. Ураховуючи, що низка споріднених кристалів із комплексами перехідних металів та алкіламонієвими катіонами виявилися магнітними мультифероїками, детальне вивчення магнітних властивостей кристала TrMAMnCl можна розглядати як дуже цікаву фундаментальну й прикладну проблему.

Дослідження монокристалів $\operatorname{TrMAMnCl}$ методом порошкової дифракції Х-променів підтвердило хімічний склад та симетрію цих монокристалів, а також дало змогу уточнити параметри кристалічної гратки порівняно з попередніми даними: $a=16.7492(7), b=7.4241(3), c=8.2119(3) \AA$ А, об'єм елементарної комірки $V=1021.13(7) \AA^{3}$.

Виміряно температурну та польову залежності намагнічення монокристалів TrMAMnCl, які засвідчили, що цей матеріал поводиться як одновимірний антиферомагнетик із нахилом спінів. Беручи до уваги дані ЕПР, вивчення магнітної питомої теплоти та структури, поведінку намагніченості можна пояснити, якщо припустити, що в досліджуваному кристалі $\epsilon$ прихований нахил спінів уздовж осі $b$. Магнітні властивості можна інтерпретувати в межах моделі, що розглядає сукупність одновимірних лінійних ланцюгів із метал-галогенних комплексів зі слабкою антиферомагнітною взаємодією як уздовж ланцюга, так і між ланцюгами, з температурою Нейля $T_{\mathrm{N}}=0.98 \mathrm{~K}$. Широкий максимум намагніченості, який спостерігався вище від температури антиферомагнітного впорядкування (при $T=2.5 \mathrm{~K}$ ), був пов'язаний із проявом ближнього порядку за аналогією зі спорідненими сполуками 3 алкіламонієвими катіонами та лінійними ланцюгами комплексів магнітних йонів. За температури, вищої від $17 \mathrm{~K}$, намагнічення кристала добре описується законом Кюрі-Вайса з температурою КюріВайса $\theta=-(6.1 \pm 0.1)$ К. Зважаючи на від'ємний знак цього параметра, можна зробити висновок, що обмінна взаємодія між йонами $\mathrm{Mn}^{2+}$ у ланцюгах за своєю природою $є$ антиферомагнітною.

Ключові слова: антиферомагнетик, магнітні властивості, намагніченість, низькорозмірні спінові системи, рентгенівська порошкова дифракція. 